\title{
DEFECT LUMINESCENCE OF YAG NANOPOWDERS AND CRYSTALS
}

\author{
L. Grigorjeva ${ }^{1 *}$, D. Jankoviča ${ }^{2}$, K. Smits ${ }^{1}$, D. Millers ${ }^{1}$, S. Zazubovich ${ }^{3}$ \\ ${ }^{1}$ Institute of Solid State Physics (LU), \\ 8 Kengaraga Str., Riga, LV-1063, LATVIA \\ ${ }^{2}$ Institute of Inorganic Chemistry (RTU), \\ 34 Miera Str., Salaspils, LV-2169, LATVIA \\ ${ }^{3}$ Institute of Physics, University of Tartu, \\ 142 Riia Str., Tartu, 51014, ESTONIA \\ *e-mail: lgrig@latnet.lv

\begin{abstract}
Undoped and rare-earth-ion-doped $\mathrm{Y}_{3} \mathrm{Al}_{5} \mathrm{O}_{12}$ (YAG) nanopowders are prepared by the sol-gel low-temperature combustion method. The luminescence characteristics of the YAG, YAG:Ce, YAG:Pr, and YAG:Ce/Pr nanopowders are compared with those of the single crystals. The luminescence band peaking around $3.1 \mathrm{eV}$ is complex and excited at about $3.6 \mathrm{eV}, 3.9 \mathrm{eV}$ and $4.3 \mathrm{eV}$. The $3.1 \mathrm{eV}$ emission was peculiar to all the samples studied. The Stokes shift of this band is $\sim 0.5$ $\mathrm{eV}$. The decay time of the $\sim 3.1 \mathrm{eV}$ emission at $80 \mathrm{~K}$ is $\sim 14 \mathrm{~ns}$ and the slower decay (afterglow) components are practically absent. The $3.1 \mathrm{eV}$ luminescence was suggested to arise from different intrinsic lattice defects.
\end{abstract}

Key words: defects, $\mathrm{Y}_{3} \mathrm{Al}_{5} \mathrm{O}_{12}$, single crystals, nanopowders, luminescence.

\section{INTRODUCTION}

The rare-earth-ion-doped $\mathrm{Y}_{3} \mathrm{Al}_{5} \mathrm{O}_{12}$ (YAG) composition is well-known material for lasers (YAG:Nd, YAG:Yb), scintillators (YAG:Ce, YAG:Pr), and white LEDs. Owing to the recently developed technology, high-quality transparent ceramics for lasers and scintillators has been obtained [1]. As a starting material for the ceramic sintering, the nanopowders (NPs) are used. The dopant luminescence was mainly studied in YAG single crystals (SCs), NPs and ceramics. However, as reported in [2], the contribution of emission in the $\sim 3.0 \mathrm{eV}$ region to the total YAG:Ce ceramics emission is high - a half of the Ce luminescence intensity. For successful applications, it is of great importance to study the defect states in the mentioned materials, especially since these states are studied to a much less extent. The main known intrinsic defects in YAG SCs are oxygen-vacancy-related defects (F- and $\mathrm{F}^{+}$-type centers) and $\mathrm{AD}$ - antisite-related defects (AD is the yttrium ion located in the aluminum site). The emission bands of $\mathrm{F}$ - and $\mathrm{F}^{+}$-type centers in YAG are located at $2.695 \mathrm{eV}$ and $3.1 \mathrm{eV}$, respectively [3, 4], with the latter being a defect-perturbed $\mathrm{F}^{+}$- center. The $\mathrm{AD}$ emission band is located at $3.33 \mathrm{eV}$ and that of the exciton localized near $\mathrm{AD}-$ at $4.11 \mathrm{eV}$; the self-trapped exciton luminescence was observed at low temperatures $[5,6]$. 
In the present work, the radio- and photoluminescence spectra, luminescence excitation spectra, and the decay kinetics of undoped and $\mathrm{Ce}^{3+}$ or/and $\mathrm{Pr}^{3+}$-doped YAG NP prepared by the sol-gel low-temperature combustion method were studied and compared with those of YAG SC. The goal of the work was to investigate the luminescence characteristics and clarify the origin of the defect-related $3.1 \mathrm{eV}$ luminescence band in the YAG SC and NP.

\section{EXPERIMENTAL}

\subsection{Sample preparation}

The powders were prepared by the sol-gel combustion method [7-9]. As starting materials, the aluminum nitrate, yttrium oxide, cerium and praseodymium nitrates were used. The following NPs were prepared: undoped, Ce-, $\mathrm{Pr}-$ and $\mathrm{Ce} / \mathrm{Pr}-$ doped. Appropriate amounts of reagents were dissolved in distilled water. The concentration of $\mathrm{Ce}^{3+}$ or $\mathrm{Pr}^{3+}$ ions was $2 \mathrm{~mol} \%$. In YAG:Ce/Pr, the total dopant concentration was also $2 \mathrm{~mol} \%$ ( $1 \mathrm{~mol} \%$ of $\mathrm{Ce}^{3+}$ and $1 \mathrm{~mol} \%$ of $\left.\operatorname{Pr}^{3+}\right)$. The solution of precursors was mixed and heated at $80-85{ }^{\circ} \mathrm{C}$, after which the nitric acid and ethylene glycol were added. The molar ratio of metal ions and ethylene glycol was $1: 2$, while that of ethylene glycol to $\mathrm{NO}_{3}{ }^{-}-0.7$. All the chemicals were of the reactive grade (supplied by Aldrich). The mixture was evaporated with stirring at $90-100{ }^{\circ} \mathrm{C}$. During evaporation a large amount of brownish gas was emitted and the solution transformed to a yellowish-white powder. The dry powder was combusted at temperatures $500-550{ }^{\circ} \mathrm{C}$ for $4 \mathrm{~h}$, and a black amorphous powder was obtained. The powders were calcinated at $1000{ }^{\circ} \mathrm{C}$ for $3 \mathrm{~h}$ in air. According to the XRD analysis, only a pure crystalline YAG cubic structure was obtained (JCPDS 00-033-0040 data). For estimation of the average grain size the specific surface area $\left(\mathrm{S}_{\mathrm{BET}}\right)$ was determined and the XRD analysis performed. The $\mathrm{S}_{\mathrm{BET}}$ was found to be in the range of $28-35 \mathrm{~m}^{2} / \mathrm{g}$, and the grain sizes ranged between $30 \mathrm{~nm}$ and $35 \mathrm{~nm}$. In SEM images, aggregates of nanoparticles (clusters) with a size larger than 2-5 $\mu \mathrm{m}$ were observed.

The YAG SCs of different origin used in this study were grown by the Czochralski method. Samples N1-N3 were undoped, sample N2 was treated under the reducing atmosphere, and sample $\mathrm{N} 4$ was Ce-doped. The absorption spectra of the studied YAG SCs are shown in Fig. 1.

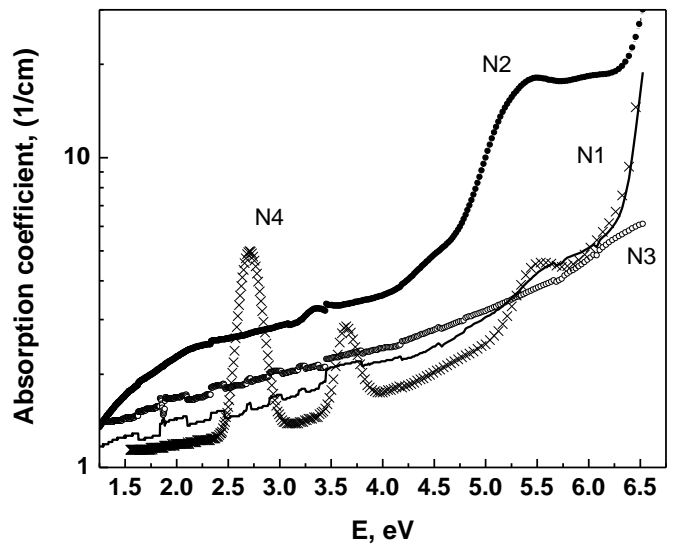

Fig. 1. RT absorption spectra of undoped YAG SC (N1-N3) and YAG:Ce SC (N4). 


\subsection{Optical measurements}

Luminescence measurements were carried out with a photon counting head (HAMAMATSU H8259-2) and a photon counting board with time bins 250 ps. The pulsed nitrogen $(337 \mathrm{~nm})$ and YAG:Nd $(266 \mathrm{~nm})$ lasers were used for studying the luminescence decay kinetics. The radioluminescence was excited with $\mathrm{X}$-rays $(30 \mathrm{kV}, 10 \mathrm{~mA})$ through a beryllium window; a SHAMROC 303 monochromator coupled with an ANDOR iDUS DU401A-BV CCD camera was used for the spectra registration. The excitation spectra were recorded at $80 \mathrm{~K}$ using a set-up consisting of two monochromators and a deuterium (DDC-400) lamp; the spectra were corrected for the spectral distribution of excitation intensity.

\section{RESULTS AND DISCUSSION}

\subsection{Radioluminescence spectra}

The luminescence in the $2.5-5.0 \mathrm{eV}$ energy range was reported earlier for the YAG SC, NP, and nanostructured ceramics $[2-6,10]$. However, the data about the luminescence mechanisms show a discrepancy.

We have compared the radioluminescence spectra measured at RT (Fig. 2) for three undoped SC samples (N1-N3) grown in different laboratories and containing dissimilar defects. The narrow lines observed in sample N2 arise from the traces of rare-earth ions. In [5], the dip in the luminescence spectrum at $\sim 3.36$ $\mathrm{eV}$ was proposed to appear due to the $\mathrm{Ce}^{3+}$ absorption. However, the undoped YAG SC under study does not contain $\mathrm{Ce}^{3+}$ ions (Fig. 1). Besides, the dip in luminescence spectra was at $3.37 \mathrm{eV}$ (see Fig. 2), which could not be due to the $\mathrm{Ce}$ absorption peaking at $3.66 \mathrm{eV}$. Our results show the presence of complex broad sample-dependent emission bands peaking at $\sim 3.1 \mathrm{eV}$ and $\sim 3.75 \mathrm{eV}$ in YAG SC.

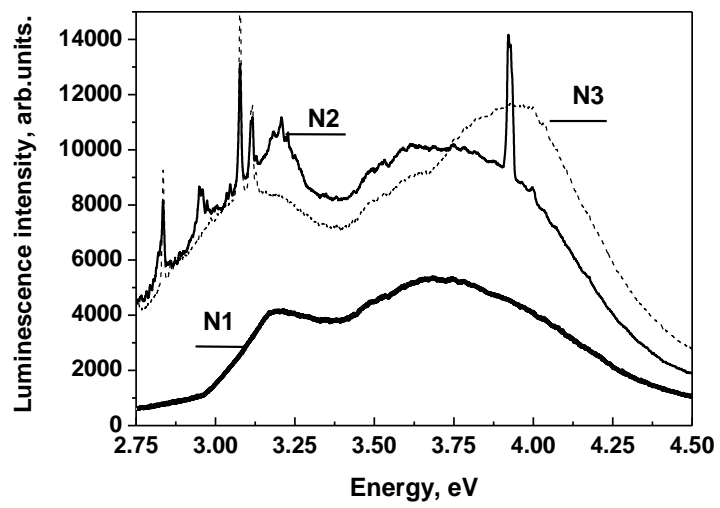

Fig. 2. RT radioluminescence spectra of YAG SC (N1-N3).

According to [5, 6], the low-energy emission band of YAG SC could be connected with $\mathrm{AD}$ peaking at $3.33 \mathrm{eV}$. However, in [10] the luminescence due to $\mathrm{AD}$ was attributed to $3.78 \mathrm{eV}$. Similar emission bands are observed in the radioluminescence spectra of YAG NP at RT (Fig. 3). The peak positions were approximately the same as those detected for YAG SC (see Fig. 2); however, one can see small shifts and broadening of emission bands in the NP samples as compared with the SC samples. 
This behaviour can be explained by assuming that the peak position depends on the grain sizes, synthesis conditions, dopant ion size and concentration, nanoparticle agglomeration, etc. This probably explains dissimilarity of YAG NP luminescence spectra obtained by different authors in the $2.75-4.25 \mathrm{eV}$ spectral range.

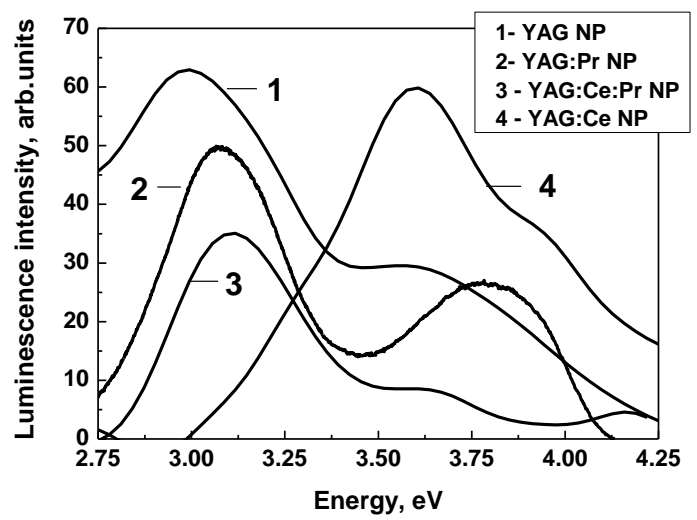

Fig. 3. RT radioluminescence spectra of different YAG NPs.

\subsection{Photoluminescence spectra and luminescence excitation spectra}

The position of YAG:Ce emission band (SC and NP) located at $\sim 3.1 \mathrm{eV}$ depends on the excitation energy (Fig. 4), which is indicative of its complex structure.
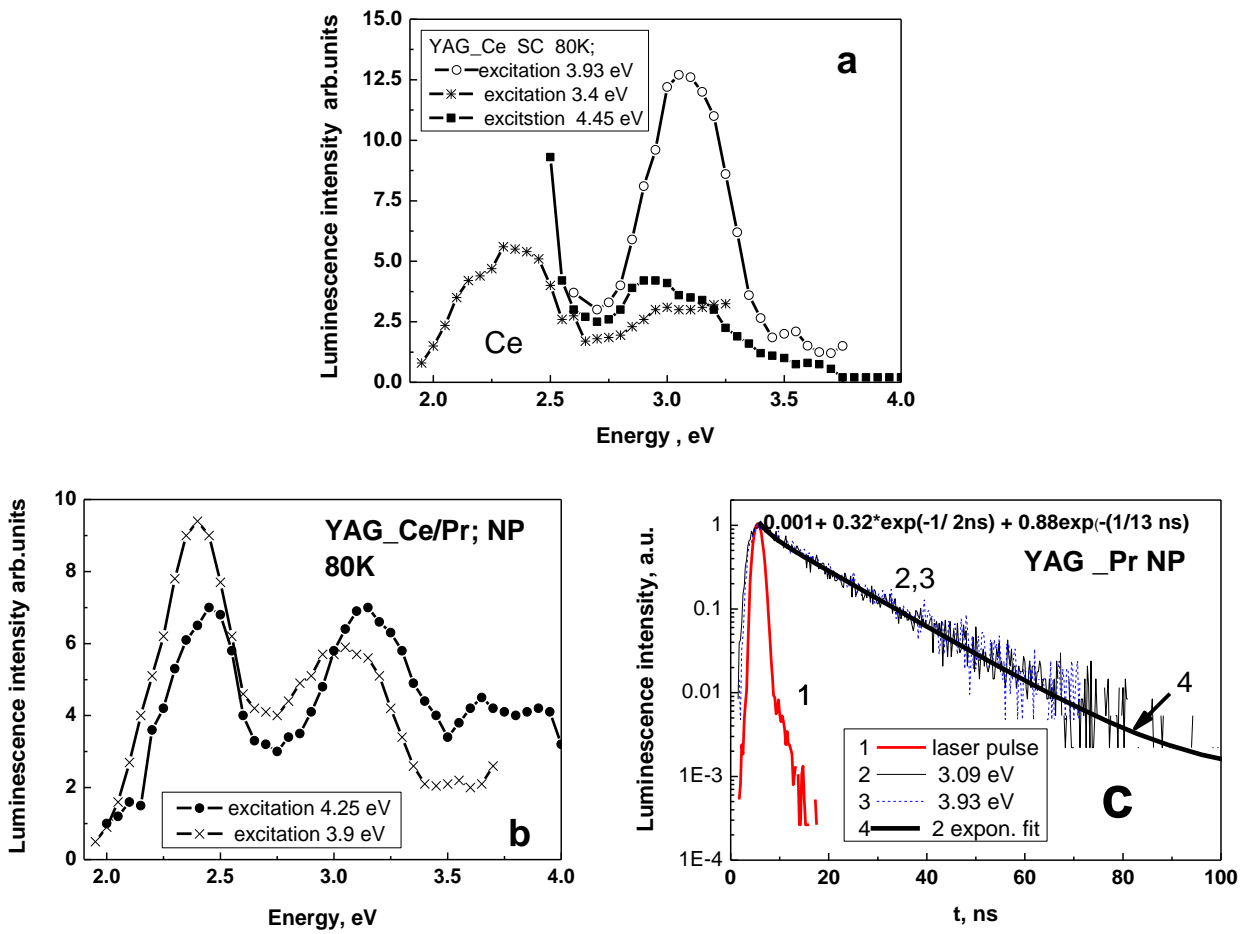

Fig. 4. Photoluminescence spectra of YAG:Ce SC $(a)$ and YAG:Ce/Pr NP $(b)$ measured at LNT under different excitation energies. The $\sim 3.1 \mathrm{eV}$ and $3.93 \mathrm{eV}$ luminescence decay kinetics measured at $80 \mathrm{~K}$ under $4.66 \mathrm{eV}$ excitation $(c)$. 
The comparison of Figs. $4 a$ and $4 b$ shows that the defect states responsible for the $\sim 3.1 \mathrm{eV}$ emission are slightly different in the SC and NP samples studied.

We have detected only a fast luminescence decay component at $80 \mathrm{~K}$ with the decay time $\sim 14 \mathrm{~ns}$ (Fig. $4 c$ ) in the decay kinetics of the $3.1 \mathrm{eV}$ emission for the SCs and NPs studied. This is longer that the decay time of luminescence bands of $\mathrm{F}^{+}$-type centres in YAG SC (3 ns at RT [4]) and LuAG SC (3.14 ns at $10 \mathrm{~K}$ [11]) located at 3.1-3.15 eV. The amplitude of afterglow did not exceed $0.01 \%$ from that of the fast component. These data indicate that the $\sim 3.1 \mathrm{eV}$ emission arises from the allowed electronic transitions.

The complex emission band around $3.1 \mathrm{eV}$ was observed in all the undoped and Ce-, Pr- or Ce/Pr-doped NPs and SCs studied. In [12], an additional emission band peaking at $\sim 3.1 \mathrm{eV}$ was observed in NP (related to the $\mathrm{Ce}^{3+}$ impurity ions). Hence, the statement expressed in [12] that this emission is peculiar to only NP and is related to $\mathrm{Ce}^{3+}$ ions is doubtful. The positions of bands in the excitation spectra of the $\sim 3.1 \mathrm{eV}$ emission in all the SCs and NPs studied are close; however, their intensity ratios in SC and NP are different (Fig. 5). In NP, this emission is excited at $\sim 3.6 \mathrm{eV}, 3.9 \mathrm{eV}$, and $4.25 \mathrm{eV}$ and the Stokes shift is $\sim 0.5 \mathrm{eV}$. In SC, the $\sim 3.1 \mathrm{eV}$ emission is mainly excited at $\sim 3.95 \mathrm{eV}$ and $\sim 4.4 \mathrm{eV}$.

The peak position of the $\sim 3.1 \mathrm{eV}$ luminescence band is close to the emission band of the $\mathrm{F}^{+}$-type center studied in work [3]. However, the $3.1 \mathrm{eV}$ emission of $\mathrm{F}^{+}$ centers in YAG is excited at $3.35 \mathrm{eV}, 5.28 \mathrm{eV}$ and $\sim 6.2 \mathrm{eV}$, its FWHM is $0.22 \mathrm{eV}$ and the Stokes shift is $\mathrm{S}=0.25 \mathrm{eV}$. Thus, the $\sim 3.1 \mathrm{eV}$ emission band studied cannot be related to the $\mathrm{F}^{+}$-type centers in $\mathrm{YAG}$.

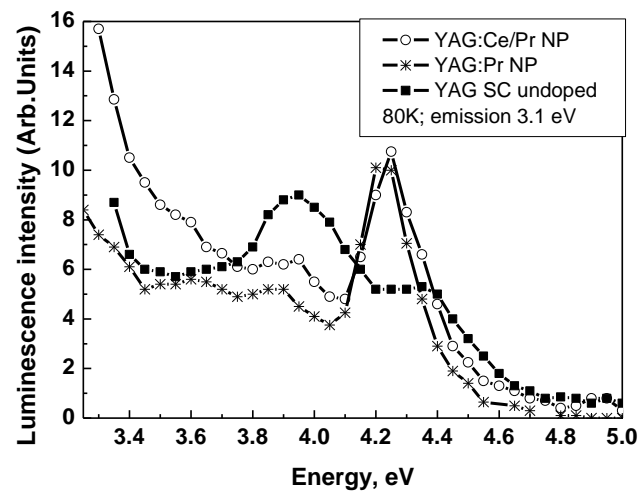

Fig.5. Excitation spectra of the $\sim 3.1 \mathrm{eV}$ luminescence of YAG:Ce/Pr NP, YAG:Pr NP, and YAG SC N1 at $80 \mathrm{~K}$.

The data obtained in this work allow us to state that the $\sim 3.1 \mathrm{eV}$ luminescence arises from an intrinsic defect of the crystal lattice. The origin of this defect needs further investigation. Its structure in SC depends on the preparation and annealing conditions. In NP, an additional perturbation can be caused by surface defects.

\section{CONCLUSIONS}

The YAG nanopowders have successfully been synthesized by the sol-gel low-temperature combustion method. However, some agglomeration of NP was 
observed. It is shown that to obtain well-separated nanoparticles additional treatment is needed. A complex luminescence band at $\sim 3.1 \mathrm{eV}$ is found in all the undoped and Ce-, Pr-doped SC and NP studied samples, which points to the intrinsic origin of this emission. The Stokes shift of this band is $\sim 0.5 \mathrm{eV}$, and the decay time is $\sim 14$ ns.

A difference in the characteristics of this emission in different SC and NP samples indicates that the intrinsic luminescence center responsible for the $\sim 3.1 \mathrm{eV}$ emission contains an additional sample-dependent perturbing defect.

\section{ACKNOWLEDGMENT}

The work was supported by Latvian Material Science Programme, LZP grant 09-1126 and Estonian Science Foundation grant No. 8678. K. Smits and Dz. Jankovica are supported by the Project Nr. 2009/0202/IDP/1.1.1.2.0/09/ APIA.VIAA/14. Authors thank M. Springis for supplying the YAG single crystal N2.

\section{REFERENCES}

1. Ikesue, A., Yan Lin Aung, Yoda, T., Nakayama, S., \& Kamimura, T. (2007). Fabrication and laser performance of polycrystal and single crystal Nd:YAG by advanced ceramic processing. Opt. Mat., 29 (10), 1289-1294.

2. Pankratov, V., Shirmane, L., Chudoba, T., Gluchowski, P., Hreniak, D., Strek, W., \& Lojkowski, W. (2010). Peculiarities of luminescent properties of cerium doped YAG transparent ceramics. Rad. Measur., 45, 392-394.

3. Pujats, A., \& Springis, M. (2001). The F-type centres in YAG crystals. Rad. Eff. and Defects in Solids, 155, 65-69.

4. Springis, M., Pujats, A., \& Valbis, J. (1991). Polarization of luminescence of colour centers in YAG crystals. J. Phys.: Condens. Mater., 3, 5457-5461.

5. Zorenko, Yu., Zorenko, T., Gorbenko, V.V., Voznyak, T., Savchyn, V., Bilski, P., \& Twardak, A. (2012). Peculiarities of luminescence and scintillation properties of YAG:Ce phosphor prepared in different crystalline forms. Opt. Mat., 34, 1314-1319.

6. Nizhankovsky, S.V., Dan'ko, A.Ya., Zelenskaya, O.V., Tarasov, V.A., Zorenko, Y.V., Pizikov, V.M., Grin, L.A., Trushkovskii, A.G., \& Savchun, V.P. (2009). Cathodoluminescence and scintillation characteristics of YAG:Ce crystals grown by horizontal directional crystallization in aprotective atmosphere. Tech. Phys. Lett., 35, 964-966.

7. De la Rosa, E, Diaz-Torres, L.A., Salas, P., Arredondo, A., Montoya, J.A., Angeles, C., \& Rodriguez, R A. (2005). Low temperature synthesis and structural characterization of nanocrystalline YAG prepared by modified sol-gel method. Opt.Mater., 27, 17931799.

8. Diaz-Torres, L.A., De la Rosa, E., Salas, P., \& Desirena, H. (2005). Enhanced cooperative absorption and upconversion in $\mathrm{Yb}^{3+}$ doped YAG nanophosphors. Opt. Mater., 27, 1305-1310.

9. Grabis, J., Jankoviča, D., Šteins, I., \& Patmalnieks, A. (2010). Preparation of YAG nanoparticles and their characteristics. Mater. Sci. Forum, 636-637, 697-702.

10. Zorenko, Yu., Zych, E., Voloshinovskii, A. (2009). Intrinsic and $\mathrm{Ce}^{3+}$-related luminescence of YAG and YAG:Ce single crystals, single crystalline films and nanopowders. Opt. Mater., 31, 1845-1848.

11. Babin, V., Laguta, V.V., Maaroos, A., Makhov, A, Nikl, M., \& Zazubovich, S. (2011). Luminescence of $\mathrm{F}^{+}$- type centers in undoped $\mathrm{Lu}_{3} \mathrm{Al}_{5} \mathrm{O}_{12}$ single crystals. Phys. Status Solidi B, 248, 239-241. 
12. Pankratov, V., Grigorjeva, L., Millers, D., \& Chudoba, T. (2007). Luminescence of cerium doped YAG nanopowders. Rad. Meas., 42, 679-682.

\section{AR DEFEKTIEM SAISTĪTĀ LUMINISCENCE YAG NANOPULVEROS UN KRISTĀLOS}

L. Grigorjeva, D. Jankoviča, K. Šmits, D. Millers, S. Zazubovičs

$$
\text { Kopsavilkums }
$$

$\mathrm{Y}_{2} \mathrm{Al}_{3} \mathrm{O}_{12}$ (YAG) kristāli ir labi paz̄istami lāzermateriāli, scintillatori, baltās gaismas emitējošās diodes. Pēdējā laikā ir izgatavotas augstas kvalitātes caurspīdīgas YAG keramikas. Pašvielas defektu pētījumi YAG kristālos, nanopulveros, plānās kārtiņās un keramikās ir aktuāli, bet rezultāti ir ļoti pretrunīgi. Neaktivētie un ar reto zemju joniem aktivētie YAG nanopulveri sintezēti ar sol-gel zemo temperatūru pašaizdegšanās (combustion) metodi. YAG, YAG:Ce, YAG:Pr un YAG:Ce/Pr nanopulveru luminiscentās īpašības salīdzinātas ar YAG monokristālu raksturīpašībām. Luminiscences josla ar maksimumu pie $3.1 \mathrm{eV}$ ir salikta un tiek ierosināta pie $3.6 \mathrm{eV}, 3.9 \mathrm{eV}$ un $4.3 \mathrm{eV}$. $3.1 \mathrm{eV}$ luminiscences josla novērota visos YAG paraugos un var secināt, ka šì josla ir raksturīga YAG materiālam. Stoksa nobīde ir $\sim 0.5 \mathrm{eV}$. Luminiscences dzīves laiks joslai pie $3.1 \mathrm{eV}$ pie $80 \mathrm{~K}$ ir $\sim 14 \mathrm{~ns}$ un lēnas dzišanas komponentes (pēcspīdēšana) praktiski nav novērojamas. Tiek apspriests $3.1 \mathrm{eV}$ luminescences centra modelis. Š̄ss centrs ir perturbēts ar defektu, kura daba un koncentrācija ir atkarīga no parauga sintēzes vai audzēšanas metodes.

17.06.2012. 